\title{
陶器焼成炉のモデリングとファジィ制御*
}

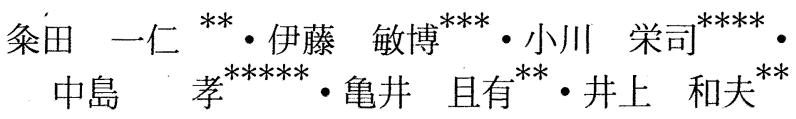

\section{A Modeling and Fuzzy Control of Ceramic Kiln*}

\author{
Kazuhito Kumeda**, Toshihiro Itou ${ }^{* * *}$, Eiji OGAWA ${ }^{* * * *}$, \\ Takashi NaKAJImA ${ }^{* * * *}$, Katsuari KAmeI ${ }^{* *}$ and Kazuo Inoue ${ }^{* *}$
}

\begin{abstract}
A ceramic kiln is a two-input/two-output system where temperature and atmosphere (hydrogen or carbon monoxide) inner it are controlled by fuel and a damper. The ceramic kiln has a huge heat capacity and is a nonlinear system because the combustion characteristics in the kiln is always changing due to interference of temperature and atmosphere. Experts, therefore, have been controlling it based on their experimental knowledge.

In this paper, we try to control the ceramic kiln by fuzzy control. First, we make a kiln model based on the combustion theory. Next, we choose membership functions of the fuzzy controller while simulating the fuzzy control of the ceramic kiln using the kiln model and fuzzy production rules given by experts. Finally, we make experiments on the fuzzy control for a real ceramic kiln in Shigaraki, Shiga Prefecture, and show some experiment results.
\end{abstract}

\section{1.まえがき}

現在使用されている陶器焼成炉の大部分は, 液化石油 ガス (LPG : Liquefied Petroleum Gas) を燃料とす るバッチ式シャトル筀である. 近年の暮らしの多様化, 個性化の進む中で，製造業に打ける高付加価值製品の多 品種少量生産は社会の要望であり, バッチ式焼成炉に よる多品種少量生産の形態は今後も続くものと考えられ る.

一方，バッチ式焼成炬による陶磁器製品の焼成では, 焼成工程により炉内の温度抢よび雲囲気（炉内空気の成

* 原稿受付 1993 年 9 月 7 日

** 立命館大学 理工学部 Department of Computer Science, Ritsumeikan University ; Noji 1916, Kusatsu city, Shiga 525, JAPAN

*** オムロン侏 電子機器統轄事業部 Development DPT., OMRON Corporation ; Simokaiinji, Nagaokakyo city, Kyoto 617, JAPAN

**** 滋賀県工業技術センター Industrial Research Center of Shiga Prefecture; Kamitoyama 232, Ritto-cho, Kurita-gun, Shiga 520-30, JAPAN

***** 滋賀県立信楽空業試験場 Shiga Prefectural Shigaraki Ceramic Research Institute ; Nagano 498, Shigarakicho, Kouka-gun, Shiga 529-18, JAPAN

Key Words : fuzzy control, ceramic kiln, kiln model, the combustion theory, temperature control, atmosphere control.
分の様子のことであり, 完全燃焼や不完全燃焼の程度を 表わすあのである. こてでは酸素濃度あるいは一酸化炭 素濃度で代表させる）を適正な值に制御する必要があり， これらの值は焼成製品の色合い，外観，品質などに大き な影響を及ぼす。乙のため, 炉内の温度や雲囲気を随時 測定しながら, 燃料ガスの供給量やエアダンパの開度 を適度に調節する必要がある。しかし，焼成炉は炉内の 温度と雾囲気の相互干渉により, その燃焼特性が複雑に 変化する非線形なシステムであり，また炉の熱容量あ非 常に大きいととから，その操作には熟練者の経験之勘が 必要となっている.

焼成工程の自動化は，近年の人手不足対応への一助之 なり，さらには焼成条件の安定化による製品の歩留り向 上や，多様化による高付加価值化，燃料ガスの供給量と 流入空気量の最適化による省エネルギー化などに大きな 効果をあたらすもの之期待される.

しかし，炉内温度に関しては，PID 調節計などにより ほぼ目的を達成しているが文, 炉内雲囲気に関しては, 依然, 熟練者によるエアダンパの手動操作, またはプ ログラム調節計などによるプログラム制御によるところ が大きい，一方，人間の扱うあいまいな情報をファジィ 集合として定量化し，人間の経験則に基づいて設定され 
た制御ルールに従って推論を実 行し制御を行うファジィ制御が, 多くの分野で応用され，その有 効性が報告されている ${ }^{2), 3)}$. 上 述の焼成工程の例のように，熟 練者の経験や勘を必要とする分 野には,ファジィ制御の適用は 非常に効果的な手段であると考 えられる.

本論文では，信楽焼焼成炬を 対象とし、ファジィ制御による 焼成工程の自動化を試みる.

ところで，焼成炉は焼成時間
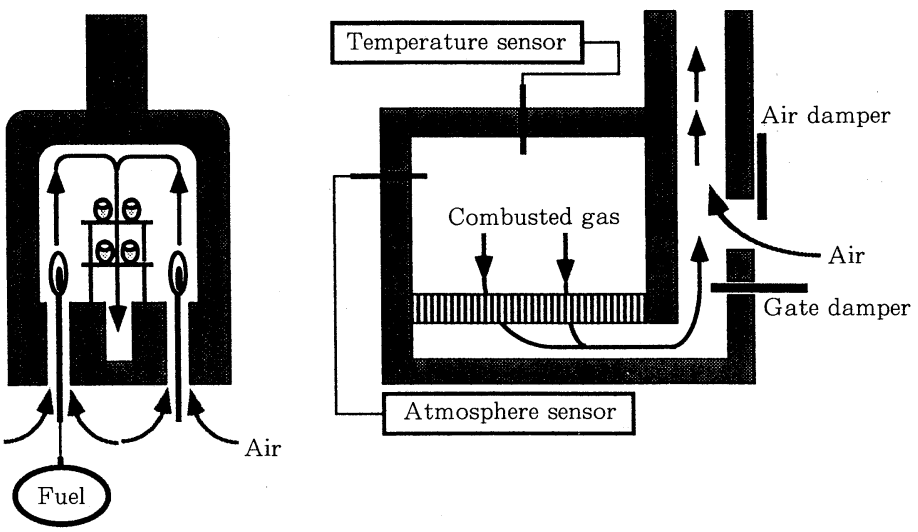

が長く，また気温や天候の違い

によって制御結果が異なる. そのため, 同じ条件のもと での実験が行えず，ファジィ制御のメンバシップ関数を 実炉を用いてチューニングすることは困難である. した がって, シミュレーションを行うためのモデルが必要と なる．そこでまず，焼成炉のモデリング4）を行う。バッ チプロセスの制御を行う場合，適切なセンサが欠如して いる場合が多いこと, この操作が非定常な状態での操 作であること, 非線形である対象を扱うことが多いてと などから，プロセスの適切なモデリングが要求される. このモデルは，単に入出力関係から作成するのではな く, 物理・化学法則を基本として求める手法が有効で ある ${ }^{5), 6)}$.つぎに，乙のモデルを用い，熟練者より得た 制御ルールからシミュレーション実験を通してファジィ 制御に招けるメンバシップ関数のチューニングを行う7). 最後に, 実炉に適用し実験を行った結果から本研究の有 効性を示す.

\section{2. 焼成炉の構造と特性および焼成方法}

\section{1 焼成炉の構造}

本研究で使用した焼成炉の仕様を Table 1 亿，構造 を.Fig. 1 に示す.

このような構造の焼成炉は, 倒炎式と呼ばれるもので,

Table 1 Specification of the kiln

\begin{tabular}{|c|c|}
\hline Name & Batch-Operated Shuttle Kiln \\
\hline Capacity & $185 \times 96 \times 120\left[\mathrm{~cm}^{3}\right]$ \\
\hline Fuel & $\begin{array}{c}\text { Liquefied Petroleum Gas } \\
\text { (butane }: \text { propane }=7: 3) \\
29 \sim 100[\ell / \mathrm{min}]\end{array}$ \\
\hline Air damper & $0 \sim 20[\mathrm{~cm}]$ \\
\hline Gate damper & $0 \sim 23[\mathrm{~cm}]$ \\
\hline Firing time & $15 \sim 18[$ hours $]$ \\
\hline
\end{tabular}

炬床両側のガスバーナより発生した火焔は側壁に沿って 上昇して天井に当たり，焼成物の間を降下して炉床中央 の煙道から煙突に排出される.

炉内の温度と雾囲気を適正な值とするために, 燃料の ガス圧の操作により炉内に供給される燃料ガスの量が調 節され，エアダンパの操作により炉内の排ガスの煙突か らの放出量が調節される.

燃焼に必要な空気は，ベンチュリー式のガスバーナの ため自然吸入であり，その流入量はエアダンパの操作に よる炉内圧力の変化により調節される. ゲートダンパは, 煙突の有効断面積を調節するために使用され，エアダン パの補助的な役割を果たしている.

ここで，炉内の温度と雾囲気は，実際には一様ではな く分布しているが，天井の空気の温度と雾囲気で代表さ せる。

\section{2 焼成炉の特性}

自然吸入式のバッチ式焼成炉では，炉内の温度は燃料 ガスの燃焼により発生する熱量と煙突より放出される排 ガスの持ち去る熱量执よび炉の温度特性により決定され， 炉内の雾囲気は炉内に吸入される空気之燃料ガスの燃焼 反応により決定される. 主として炉内温度は燃料ガスに よって, 雾冊気はエアダンパによって変化するが, これ らは互いに干渉し合い, 燃料ガスの供給量とエアダンパ の開度を入力，炬内温度と雾囲気を出力とする，2 入力 2 出力の非線形なシステムを構成している.

\section{3 焼成方法}

焼成方法には，酸化焼成 (O.F. : Oxidized Firing) と還元焼成 (R.F. : Reduced Firing) の 2 種類があ る.

酸化焼成では，焼成行程中すべて完全燃焼の状態で 素地や釉薬中に含まれる酸化金属物と酸素を結合させ ながら焼成を行う。還元焼成では，焼成の途中から不 
完全燃焼の状態とし酸化金属物から酸素を奪い取りな がら焼成を行う。酸化焼成と還元焼成とでは, 同じ釉 薬を使用していても焼き上がったときの色つやが全く 異なったものとなる，たとえば，銅を含む釉薬を用い ると酸化焼成では緑色となり，還元焼成では赤色とな る.

\section{3. 焼成炉のモデリング}

\section{1 焼成炉の物理モデル}

以下のように, 焼成炉の各変数を定める.

$Q_{1}:$ 炉に加える熱量 $[\mathrm{cal} / \mathrm{min}]$

$Q_{2}:$ 煙突から流出する熱量 $[\mathrm{cal} / \mathrm{min}]$

$T_{0}:$ 外気温度 $\left[{ }^{\circ} \mathrm{C}\right]$

$T_{1}:$ 炉内の空気の温度 $\left[{ }^{\circ} \mathrm{C}\right]$

$T_{2}:$ 炉壁の温度 $\left[{ }^{\circ} \mathrm{C}\right]$

$T_{3}:$ 焼成物の温度 $\left[{ }^{\circ} \mathrm{C}\right]$

$C_{1}:$ 炉内の空気の熱容量 $\left[\mathrm{cal} /{ }^{\circ} \mathrm{C}\right]$

$C_{2}$ : 炉壁の熱容量 $\left[\mathrm{cal} /{ }^{\circ} \mathrm{C}\right]$

$C_{3}:$ 焼成物の熱容量 $\left[\mathrm{cal} /{ }^{\circ} \mathrm{C}\right]$

$R_{1}$ : 炉内の空気と炉壁との熱抵抗 $\left[\mathrm{cal} / \mathrm{min} \cdot{ }^{\circ} \mathrm{C}\right]$

$R_{2}$ : 炉壁と炉の周囲（大気）との熱抵抗 $[\mathrm{cal} / \mathrm{min}$ ・ $\left.{ }^{\circ} \mathrm{C}\right]$

$R_{3}$ : 炬内の空気と焼成物之の熱抵抗 $\left[\mathrm{cal} / \mathrm{min} \cdot{ }^{\circ} \mathrm{C}\right]$ 炉内空気, 炉壁, 焼成物に対する熱勘定式はそれぞれ (1)〜（3）式のようになる。ただし，簡単のため炉内で の温度分布は一様とする.

$$
\begin{aligned}
& C_{1} d T_{1}+\frac{1}{R_{1}}\left(T_{1}-T_{2}\right) d t+\frac{1}{R_{3}}\left(T_{1}-T_{3}\right) d t \\
& \quad=Q_{1} d t-Q_{2} d t \\
& C_{2} d T_{2}+\frac{1}{R_{2}}\left(T_{2}-T_{0}\right) d t+\frac{1}{R_{1}}\left(T_{2}-T_{1}\right) d t=0 \\
& C_{3} d T_{3}+\frac{1}{R_{3}}\left(T_{3}-T_{1}\right) d t=0
\end{aligned}
$$

ここで, 外気温度 $T_{0}$ を一定であるとし, 以下のように 変数を置き換える.

$$
\begin{aligned}
& T_{1}^{*}=T_{1}-T_{0} \\
& T_{2}^{*}=T_{2}-T_{0} \\
& T_{3}^{*}=T_{3}-T_{0}
\end{aligned}
$$

また，入熱の合計 $Q_{1}$ と排ガスによる熱損失 $Q_{2}$ の差を $Q$ 亡置く.

$$
Q=Q_{1}-Q_{2}
$$

これにより，次の状態方程式が得られる. $\frac{d}{d t}\left[\begin{array}{c}T_{1}^{*} \\ T_{2}^{*} \\ T_{3}^{*}\end{array}\right]$

$=\left[\begin{array}{ccc}-\left(\frac{1}{C_{1} R_{1}}+\frac{1}{C_{1} R_{3}}\right) & \frac{1}{C_{1} R_{1}} & \frac{1}{C_{1} R_{3}} \\ \frac{1}{C_{2} R_{1}} & -\left(\frac{1}{C_{2} R_{1}}+\frac{1}{C_{2} R_{2}}\right) & 0 \\ \frac{1}{C_{3} R_{1}} & 0 & -\frac{1}{C_{3} R_{3}}\end{array}\right]$

$$
\times\left[\begin{array}{c}
T_{1}^{*} \\
T_{2}^{*} \\
T_{3}^{*}
\end{array}\right]+\left[\begin{array}{c}
\frac{1}{C_{1}} \\
0 \\
0
\end{array}\right] Q
$$

入熱の合計 $Q_{1}$ から排ガスによる熱損失 $Q_{2}$ を差し引 いた $Q$ が炉の温度上昇に対する入力となるが, $Q_{1}, Q_{2}$ は空気量に左右される. したがって, 焼成炉は, 操作量 である燃料の量やダンパの開度に対して非線形な特性 を持つととになり, 空気量のモデリングは非常に重要な あのとなる.

また，炉の温度に対するモデルとしては，炉の時定数 に対しサンプリング間隔を十分小さくとることで, サン プリング時間内で $Q_{1}, Q_{2}$ が一定であると見なすことに より，ステップ応答モデル6) を作成することが可能であ る.

\section{2 燃焼理論の焼成炉への適用}

化学・物理法則等で求められる燃焼理論8),9) を焼成炉 に適用し，モデリングを行う上での基本計算式を求める. 本焼成炉において測定可能な值は, 燃料ガス供給量, 夕゙ ンパ開度, 酸素濃度, 一酸化炭素濃度, 炉内温度の五 つである.乙こで, 燃焼反応や計測のむだ時間は無視で きるあのとする.

まず, 燃料ガス供給量, 酸素濃度, 一酸化炭素濃度が センサで測定されているとき, 流入空気量と炉の温度上 昇に利用される熱量を計算する.

燃料ガス供給量を $F$, センサでの酸素濃度の測定值を $y_{O 2}$, 一酸化炭素濃度の測定值を $y_{C O}$ とすると, 流入空 気量 $B$ の逆算式は次のようになる (付録 1 参照).

$$
B=\frac{6.05-2.35 y_{O 2}+\frac{2.35 \times 4.2-8.9 \times 6.05}{3.7} y_{C O}}{0.21-y_{O 2}+\frac{4.2-0.21 \times 8.9}{3.7} y_{C O}} F
$$

$B$ : 流入空気量 $[\ell / \mathrm{min}]$

$y_{O 2}:$ 酸素濃度の測定値 $[\% / 100]$ 
$y_{C O}$ : 一酸化炭素濃度の測定值 $[\% / 100]$

$F$ : 燃料ガス供給量 $[\ell / \mathrm{min}]$

また，焼成炉の熱勘定より，外気温度を $T_{0}$, 炉内温度 を $T_{1}$, 完全燃焼する燃料の量を $F_{1}$, 不完全燃焼する燃 料の量を $F_{2}$ とすると, 炉の温度上昇に利用される熱量 $Q$ は次式で表わされる（付録 2 参照).

$$
\begin{aligned}
& Q=110295 F_{1}+12851 F_{2} \\
& -\left(B+2.35 F_{1}+6.55 F_{2}\right) \frac{2.5 \times 8.31}{\left(1+\frac{T_{0}}{273}\right) \times 22.4}\left(T_{1}-T_{0}\right)
\end{aligned}
$$

$Q:$ 炉の温度上昇に利用される熱量 $[\mathrm{J} / \mathrm{min}]$

$F_{1}:$ 完全燃焼する燃料の量 $[\ell / \mathrm{min}]$

$F_{2}$ : 不完全燃焼する燃料の量 $[\ell / \mathrm{min}]$

$B:$ 流入空気量 $[\ell / \mathrm{min}]$

$T_{0}:$ 外気温度 $\left[{ }^{\circ} \mathrm{C}\right]$

$T_{1}:$ 炉内温度 $\left[{ }^{\circ} \mathrm{C}\right]$

ここで, $F_{1}, F_{2}$ は次式により与えられる.

$$
F_{1}=\frac{3.7\left(0.21-y_{O 2}\right)+(-1.85-0.21 \times 6.55) y_{C O}}{3.7\left(0.21-y_{O 2}\right)+(4.2-0.21 \times 8.9) y_{C O}} F
$$

$$
F_{2}=\frac{(6.05-0.21 \times 2.35) y_{C O}}{3.7\left(0.21-y_{O 2}\right)+(4.2-0.21 \times 8.9) y_{C O}} F
$$

$F_{1}$ : 完全燃焼する燃料の量 $[\ell / \mathrm{min}]$

$F_{2}$ : 不完全燃焼する燃料の量 $[\ell / \mathrm{min}]$

$y_{O 2}:$ 酸素濃度の測定值 $[\% / 100]$

$y_{C O}:$ 一酸化炭素濃度の測定値 $[\% / 100]$

$F$ : 燃料ガス供給量 $[\ell / \mathrm{min}]$

つぎに, 流入空気量の推定值を $\hat{B}$ と定義し, 酸素濃度 の推定值 $\hat{y}_{O 2}$, 一酸化炭素濃度の推定值 $\hat{y}_{C O}$ を求める計 算式を示す.

燃料の量 $F$ の燃料組成は, ブタン: プロパン $=7: 3$ である．また，空気の組成を窒素：酸素 $=79: 21$ とする と, ブタン, プロパンの完全燃焼式から, 燃料 $F$ が完 全燃焼するためには $(605 / 21) F$ の空気が必要である. あし, 流入空気量の推定值 $\hat{B}$ が

$$
\hat{B} \geq \frac{605}{21} F
$$

\section{$\hat{B}$ : 流入空気量の推定値 $[\ell / \mathrm{min}]$}

$F:$ 燃料ガス供給量 $[\ell / \mathrm{min}]$

の場合は，燃料 $F$ はすべて完全燃焼し，以下の式を得 る.

$$
\begin{aligned}
& F_{1}=F \\
& F_{2}=0
\end{aligned}
$$

$$
\begin{aligned}
& \hat{y}_{O 2}=\frac{0.21 \hat{B}-6.05 F}{\hat{B}-2.35 F} \\
& \hat{y}_{C O}=0
\end{aligned}
$$

$F_{1}$ : 完全燃焼する燃料の量 $[\ell / \mathrm{min}]$

$F_{2}$ : 不完全燃焼する燃料の量 $[\ell / \mathrm{min}]$

$\hat{y}_{O 2}$ : 酸素濃度の推定值 $[\% / 100]$

$\hat{y}_{C O}$ : 一酸化炭素濃度の推定值 $[\% / 100]$

$\hat{B}$ : 流入空気量の推定值 $[\ell / \mathrm{min}]$

$F$ : 燃料ガス供給量 $[\ell / \mathrm{min}]$

逆に, 燃料 $F$ と流入空気量の推定值 $\hat{B}$ の関係が

$$
\hat{B}<\frac{605}{21} F
$$

$\hat{B}:$ 流入空気量の推定值 $[\ell / \mathrm{min}]$

$F:$ 燃料ガス供給量 $[\ell / \mathrm{min}]$

の場合，不完全燃焼を生じ以下の式を得る.

$$
\begin{aligned}
& F_{1}=\frac{1}{4.2}(0.2 \hat{B}-1.85 F) \\
& F_{2}=\frac{1}{4.2}(-0.21 \hat{B}+6.05 F) \\
& \hat{y}_{O 2}=0
\end{aligned}
$$

$\hat{y}_{C O}=\frac{3.7(-0.21 \hat{B}+6.05 F)}{(4.2-8.9 \times 0.21) \hat{B}+(8.9 \times 6.05-4.2 \times 2.35) F}$

$F_{1}$ : 完全燃焼する燃料の量 $[\ell / \mathrm{min}]$

$F_{2}$ : 不完全燃焼する燃料の量 $[\ell / \mathrm{min}]$

$\hat{y}_{O 2}$ : 酸素濃度の推定値 $[\% / 100]$

$\hat{y}_{C O}$ : 一酸化炭素濃度の推定值 $[\% / 100]$

$\hat{B}$ : 流入空気量の推定值 $[\ell / \mathrm{min}]$

$F$ : 燃料ガス供給量 $[\ell / \mathrm{min}]$

また, このとき温度上昇に利用される熱量 $Q$ について は, (10) 式をそのまま使用することができる.

\section{3 流入空気量のモデリング}

燃料やダンパの変化に対する雾囲気の時定数は，温 度特性のそれと比較してかなり小さい。そこで，雾囲気 は静特性のみ考慮する.

焼成炉に流入する空気量は，燃料ガス供給量や通風力 に関係する，通風力とは，空気の密度や煙突の高さ，排 ガスが煙道を通過するときの摩擦による抵抗，ダンパ による抵抗等によって決まる值である。しかし，てれら のパラメータをすべて求めるのは困難であるため, 乙こ では流入空気量をまとめて燃料の量 $F$, ダンパの開度 $D$, 炉内温度 $T_{1}$ による関数として扱うことにする.

流入空気量 $B$ の逆算式 (9) 式を用いることで, 焼成 炉の操業データから流入空気量の計算值が得られる．乙 れを図示すると Fig.2 のようになる.乙こで，ダンパ 


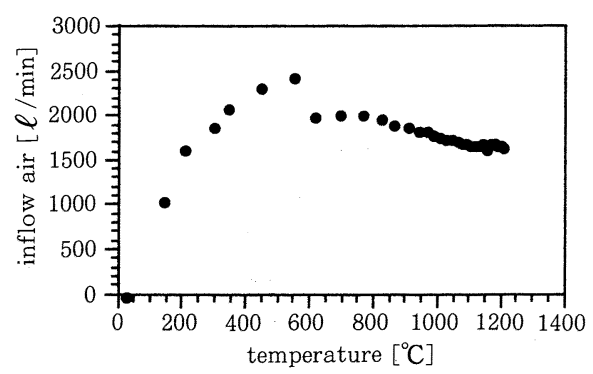

Fig. 2 Inflow air into the kiln

の開度は, $0 \sim 600{ }^{\circ} \mathrm{C}$ は全閉であり, $600 \sim 1040{ }^{\circ} \mathrm{C}$ で一定 量開けている. ての図より流入空気量の推定值 $\hat{B}$ の形 状を

$$
\hat{B}=k_{1} e^{-a_{1} D} F^{a_{2}}\left\{e^{-b_{1}\left(T_{1}-T_{0}\right)}-e^{-b_{2}\left(T_{1}-T_{0}\right)}\right\}
$$

$\hat{B}:$ 流入空気量の推定值 $[\ell / \mathrm{min}]$

$D:$ ダンパ開度 $[\mathrm{cm}]$

$F:$ 燃料ガス供給量 $[\ell / \mathrm{min}]$

$T_{0}:$ 外気温度 $\left[{ }^{\circ} \mathrm{C}\right]$

$T_{1}:$ 炉内温度 $\left[{ }^{\circ} \mathrm{C}\right]$

と仮定し, 操業データと推定值の誤差の二乗和が最小に なるように (23) 式の各パラメー夕を求める. 探索方法 としては山登りを行っており, 単純降下法 ${ }^{10)}$ を繰り返 している. 探索結果は次のとおりである.

$$
\begin{aligned}
& k_{1}=2230 \\
& a_{1}=0.01520 \\
& a_{2}=0.110 \\
& b_{1}=0.0005270 \\
& b_{2}=0.005330
\end{aligned}
$$

このとき, 炉内には流入空気以外に最初から空気が存在 し，その影響が 10 分程度あると考えられる. そのため, パラメータ同定に用いるデータは焼成開始 10 分後以降 のあのとする.

\section{4 炉内温度のモデリング}

（8）式は 3 次の微分方程式であるが，乙こでは簡単の ため, 炉壁と焼成物を一体と見なして 2 次の微分方程式 でモデリングを行う.

炉内温度の推定值 $\hat{T}_{1}$ の形状を

$$
\begin{aligned}
& \hat{T}_{1}(i+1) \\
& = \begin{cases}g_{i} Q(0)+T_{0} & (i=0) \\
\sum_{j=0}^{i} g_{j} \Delta Q(i-j)+g_{i} Q(0)+T_{0} & (i=1,2, \cdots)\end{cases}
\end{aligned}
$$

ここで

$$
\begin{aligned}
& g_{j}=k_{2}\left\{1-a_{3} e^{-b_{3} j \Delta t}-a_{4} e^{-b_{4} j \Delta t}\right\} \\
& \Delta Q(i-j)=Q(i-j)-Q(i-j-1)
\end{aligned}
$$

$\hat{T}_{1}:$ 炉内温度の推定値 $\left[{ }^{\circ} \mathrm{C}\right]$

$Q$ : 炉の温度上昇に利用される熱量 $[\mathrm{J} / \mathrm{min}]$

$T_{0}:$ 外気温度 $\left[{ }^{\circ} \mathrm{C}\right]$

$\Delta t:$ サンプリング時間 [ $\mathrm{min}]$

之仮定する.入力である燃料ガス供給量 $F$ とダンパ 開度 $D$ については焼成炉の操業デー夕を用い, また, 流入空気量の推定值 $\hat{B}$ を利用して, 設定した微小時間 $\Delta t$ ごとに炉内温度の推定值 $\hat{T}_{1}$ を計算し, 操業データと 推定值の誤差の二乗和が最小になるように (24) 式の各 パラメータを求める. また, 3.3 で述べたように, 炉内 には最初から空気が存在する. この空気量を $B_{0}$ とし, 流入空気量の初期值と見なして同様にして求める. 探索 方法としては, 流入空気量の場合と同様山登りを行って おり，単純降下法を繰り返している．探索結果は次のと おりである。

$$
\begin{aligned}
& k_{2}=0.0003190 \\
& a_{3}=0.769 \\
& a_{4}=0.231 \\
& b_{3}=0.001490 \\
& b_{4}=0.290 \\
& B_{0}=3000
\end{aligned}
$$

以上より，あるサンプリング時刻 $i$ において，燃料ガ 供給量 $F(i)$ とダンパ開度 $D(i)$ が与えられると, (10), (13)〜 (22) 式より, 同サンプリング時刻での炉の 温度上昇に利用される熱量 $Q(i)$ が導出され，(24) 式 より次のサンプリング時刻での炉内温度 $\hat{T}_{1}(i+1)$ が推 定される. 続いて, (23) 式より, 次のサンプリング時 刻での流入空気量 $\hat{B}(i+1)$. が推定され，(13) (22) 式 より, 次のサンプリング時刻での炉内雾囲気の推定值 $\hat{y}_{O 2}(i+1), \hat{y}_{C O}(i+1)$ が導出される. ただし, 流入空 気量の初期值として最初に炉内に存在する空気量 $B_{0}$ を 与えておく必要がある.

\section{4. 焼成炉のファジィ制御}

\section{1 システム構成と推論形式}

本ファジィシステムの構成図を Fig. 3 に示し, その 入出力変数を以下に定義する.

$i:$ サンプリング時刻

$r_{T}:$ 目標温度 $\left[{ }^{\circ} \mathrm{C}\right]$

$r_{O 2}:$ 目標酸素濃度 $[\%]$

$r_{C O}:$ 目標一酸化炭素濃度 $[\%]$

$y_{T}:$ 測定温度 $\left[{ }^{\circ} \mathrm{C}\right]$ 


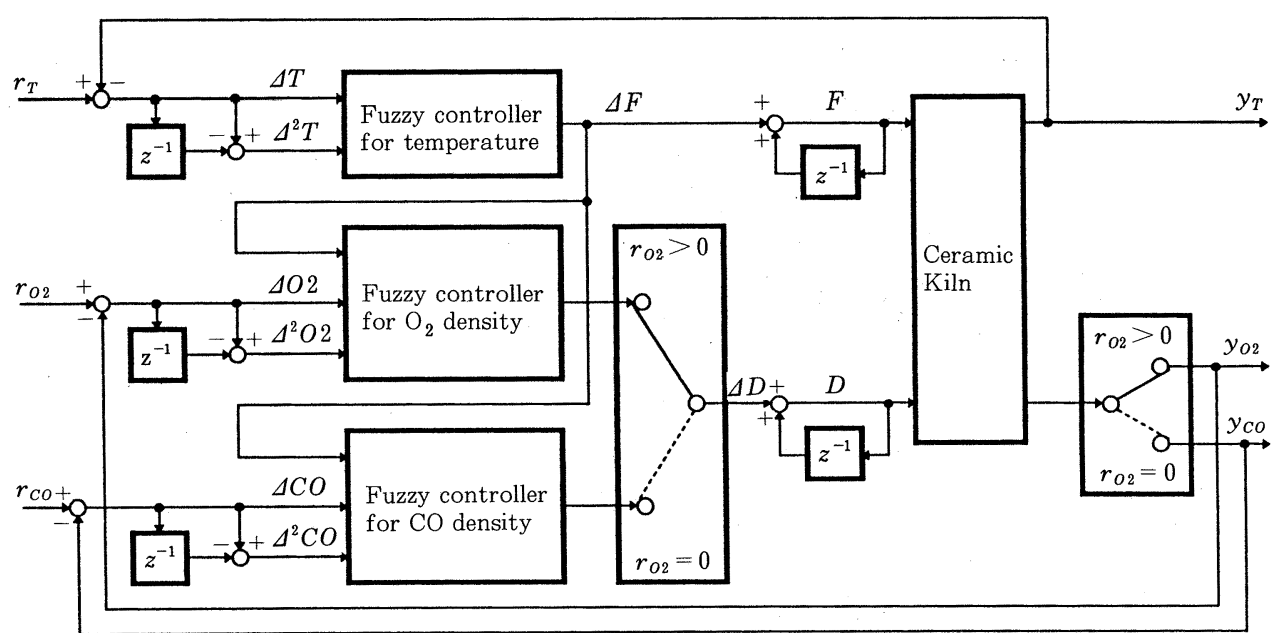

Fig. 3 Fuzzy control system

$y_{O 2}:$ 測定酸素温度 $[\%]$

$y_{C O}:$ 測定一酸化炭素濃度 $[\%]$

$\Delta T$ : 温度偏差 $\left[{ }^{\circ} \mathrm{C}\right]$

$$
\Delta T(i)=r_{T}(i)-y_{T}(i)
$$

$\Delta O 2$ : 酸素濃度偏差 [\%]

$$
\Delta O 2(i)=r_{O 2}(i)-y_{O 2}(i)
$$

$\triangle C O$ : 一酸化炭素濃度偏差 [\%]

$$
\Delta C O(i)=r_{C O}(i)-y_{C O}(i)
$$

$\Delta^{2} T$ : 温度偏差の変化分 $\left[{ }^{\circ} \mathrm{C} / \mathrm{min}\right]$

$$
\Delta^{2} T(i)=\Delta T(i)-\Delta T(i-1)
$$

$\Delta^{2} \mathrm{O} 2$ : 酸素濃度偏差の変化分 $[\% / \mathrm{min}]$

$$
\Delta^{2} O 2(i)=\Delta O 2(i)-\Delta O 2(i-1)
$$

$\Delta^{2} C O$ : 一酸化炭素濃度偏差の变化分 $[\% / \mathrm{min}]$

$$
\Delta^{2} C O(i)=\Delta C O(i)-\Delta C O(i-1)
$$

$\Delta F$ : 燃料ガス供給量の増加分 $[\ell / \mathrm{min}]$

$\Delta D$ : エアダンパ開度の増加分 $[\mathrm{cm}]$

自然吸入式のバッチ式焼成炉では，炉内の温度と雾囲 気が互いに影響を及ぼし合っているため，炉内の温度と 雾井気をそれぞれ別々にフィードバックして制御を行お うとすると，燃料とエアダンパの操作に互いに矛盾を 生じることがあり，炉内の燃焼状態が不安定となること がある.

そこで，本システムでは，まず炉内温度より燃料ガス の供給量を推論し，つぎに，得られた燃料ガス供給量と 炉内雾囲気からエアダンパの開度を推論する．乙のよ うに, エアダンパ開度の推論時に燃料ガス供給量を考 慮に入れることで, 燃料とエアダンパ間の操作の矛盾 と, 温度と雾囲気の相互間の悪影響を未然に防止でき, 安定かつ効率のよい燃焼が行えると考えられる．乙こで,
2.3 であ述べたように，炉内雾囲気には完全燃焼状態よ 不完全燃焼状態の二つの状態が存在する，完全燃焼時で は酸素濃度を, 不完全燃焼時では一酸化炭素濃度を, そ れぞれ適正な值に制御する必要がある.そこで，エアダ ンパ開度の推論では, 完全燃焼時では酸素濃度に, 不 完全燃焼時では一酸化炭素濃度に着目する.

また，推論方法としては， $\max -\min$ 合成を行い， 重心法を用いて非ファジィ化する ${ }^{2)}$.

\section{2 メンバシップ関数}

本システムで使用するメンバシップ関数の形状は，ファ ジィ推論処理の高速化を図るため，互いに 0.5 で交わる 二等辺三角形型とし，そのラベルは推論ルールの煩雑化 を防ぐため, 入出力とも $\mathrm{N}$ (Negative), Z (Zero), P (Positive) の 3 種類とする.

これらのメンバシップ関数のパラメータ值は，実炉を 用いてチューニングを行うことは困難なので, 上述の焼 成炉のモデルを用い，シミュレーションを通して試行錯 誤的にチューニングしたものである。

完全燃焼時のメンバシップ関数を Fig. 4 に示す.

\section{3 推論ルール}

推論ルールに扔いて, 燃料ガス供給量の推論ルールに は 9 個, エアダンパ開度の推論ルールには完全燃焼時 と不完全燃焼時にそれぞれ 27 個のルールを用意した. また，乙れらのルールは，熟練者からの操炉に関するア ンケート結果に基づいて設定したものである.

燃料ガス供給量の推論ルールでは，目標温度と炉内の 測定温度の偏差 $\Delta T$ および偏差の变化分 $\Delta^{2} T$ より，燃 料ガス供給量の増加分 $\Delta F$ を推論する. また, 完全燃焼, 不完全燃焼の区別なく同一の推論ルールを使用する.

エアダンパの開度の推論ルールでは, まず完全燃焼 

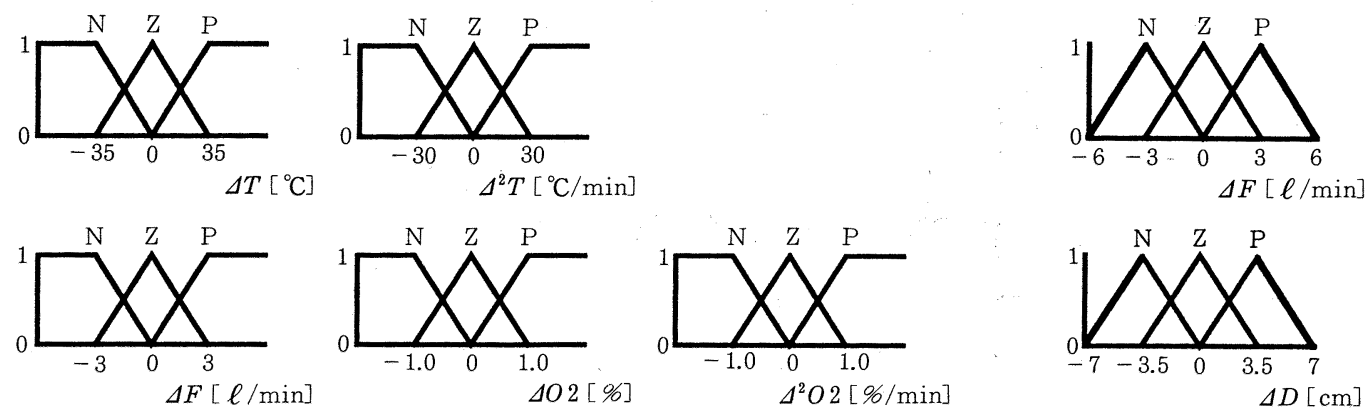

(a) Antecedent part

(b) Consequent part

Fig. 4 Membership functions in perfect combustion

Table 2 Rule tables

(a) Rule table of fuel in perfect combustion

\begin{tabular}{|c|cc|c|}
\hline Rule. No. & $\Delta T$ & $\Delta^{2} T$ & $\Delta F$ \\
\hline 1 & $\mathrm{~N}$ & $\mathrm{~N}$ & $\mathrm{~N}$ \\
2 & $\mathrm{~N}$ & $\mathrm{Z}$ & $\mathrm{N}$ \\
3 & $\mathrm{~N}$ & $\mathrm{P}$ & $\mathrm{Z}$ \\
4 & $\mathrm{Z}$ & $\mathrm{N}$ & $\mathrm{N}$ \\
5 & $\mathrm{Z}$ & $\mathrm{Z}$ & $\mathrm{Z}$ \\
6 & $\mathrm{Z}$ & $\mathrm{P}$ & $\mathrm{P}$ \\
7 & $\mathrm{P}$ & $\mathrm{N}$ & $\mathrm{Z}$ \\
8 & $\mathrm{P}$ & $\mathrm{Z}$ & $\mathrm{P}$ \\
9 & $\mathrm{P}$ & $\mathrm{P}$ & $\mathrm{P}$ \\
\hline
\end{tabular}

(b) Rule table of air damper in perfect combustion

\begin{tabular}{|c|c|c|c|c|}
\hline Rule. No. & $\Delta F$ & $\triangle O 2$ & $\Delta^{2} O 2$ & $\Delta D$ \\
\hline 1 & $\mathrm{~N}$ & $\mathrm{~N}$ & $\mathrm{~N}$ & $\mathrm{P}$ \\
\hline 2 & $\mathrm{~N}$ & $\mathrm{~N}$ & $\mathrm{Z}$ & $\mathrm{P}$ \\
\hline 3 & $\mathrm{~N}$ & $\mathrm{~N}$ & $\mathrm{P}$ & $\mathrm{P}$ \\
\hline 4 & $\mathrm{~N}$ & $Z$ & $\mathrm{~N}$ & $\mathrm{P}$ \\
\hline 5 & $\mathrm{~N}$ & Z & Z & $\mathrm{P}$ \\
\hline 6 & $\mathrm{~N}$ & Z & $\mathrm{P}$ & Z \\
\hline 7 & $\mathrm{~N}$ & $\mathrm{P}$ & $\mathrm{N}$ & $N$ \\
\hline 8 & $\mathrm{~N}$ & $\mathrm{P}$ & Z & $\mathrm{N}$ \\
\hline 9 & $\mathrm{~N}$ & $\mathrm{P}$ & $\mathrm{P}$ & $\mathrm{N}$ \\
\hline 10 & Z & $\mathrm{N}$ & $\mathrm{N}$ & $\mathrm{P}$ \\
\hline 11 & Z & $\mathrm{N}$ & $\mathrm{Z}$ & $\mathrm{P}$ \\
\hline 12 & Z & $\mathrm{N}$ & $\mathrm{P}$ & Z \\
\hline 13 & Z & Z & $\mathrm{N}$ & $\mathrm{P}$ \\
\hline 14 & $\mathrm{Z}$ & Z & Z & Z \\
\hline 15 & Z & Z & $\mathrm{P}$ & $\mathrm{N}$ \\
\hline 16 & $\mathrm{Z}$ & $\mathrm{P}$ & $\mathrm{N}$ & Z \\
\hline 17 & Z & $\mathrm{P}$ & Z & $\mathrm{N}$ \\
\hline 18 & Z & $\mathrm{P}$ & $\mathrm{P}$ & $\mathrm{N}$ \\
\hline 19 & $\mathrm{P}$ & $N$ & $\mathrm{~N}$ & $\mathrm{P}$ \\
\hline 20 & $\mathrm{P}$ & $N$ & Z & $\mathrm{P}$ \\
\hline 21 & $\mathrm{P}$ & $\mathrm{N}$ & $\mathrm{P}$ & $\mathrm{P}$ \\
\hline 22 & $\mathrm{P}$ & $\mathrm{Z}$ & $\mathrm{N}$ & Z \\
\hline 23 & $\mathrm{P}$ & Z & $\mathrm{Z}$ & $\mathrm{N}$ \\
\hline 24 & $\mathrm{P}$ & Z & $\mathrm{P}$ & $\mathrm{N}$ \\
\hline 25 & $\mathrm{P}$ & $\mathrm{P}$ & $\mathrm{N}$ & $\mathrm{N}$ \\
\hline 26 & $\mathrm{P}$ & $\mathrm{P}$ & $\mathrm{Z}$ & $\mathrm{N}$ \\
\hline 27 & $\mathrm{P}$ & $\mathrm{P}$ & $\mathrm{P}$ & $\mathrm{N}$ \\
\hline
\end{tabular}

時は，上で得られた燃料ガス供給量の増加分 $\Delta F$ 之目標 酸素濃度と炉内の測定酸素濃度の偏差 $\Delta O 2$, 偏差の变 化分 $\Delta^{2} O 2$ よりエアダンパ開度の増加分 $\Delta D$ を推論
する，不完全燃焼時は，同様に $\Delta F$ 之目標一酸化炭素濃 度と炬内の測定一酸化炭素濃度の偏差 $\triangle C O$, 偏差の変 化分 $\Delta^{2} C O$ より $\Delta D$ を推論する. これらのルールの切 り換え条件となる完全燃焼，不完全燃焼の判断は，目標 酸素濃度が零より大きければ完全燃焼，零であれば不完 全燃焼とする。

燃料ガス供給量の推論ルールおよび完全燃焼時のエ アダンパ開度の推論ルールを. それぞれ Table 2 に示 す.

ここで, エアダンパ開度の推論ルールにおいて, 完全 燃焼と不完全燃焼は逆の特性を示すので, これらの推論 ルールは対照的なるのとなる. たとえば, Table 2 (b) の完全燃焼時のルール 1 は, 「燃料ガス供給量が減少し $(\Delta F=\mathrm{N})$, 酸素濃度が目標值よりあ高く $(\Delta O 2=\mathrm{N})$ か つ上昇中 $\left(\Delta^{2} O 2=\mathrm{N}\right)$ ならば，エアダンパの開度を大 きくする $(\Delta D=\mathrm{P})$.」という意味を持つ. 一方, 不完 全燃焼時では,「燃料ガス供給量が減少し $(\Delta F=\mathrm{N})$, 一酸化炭素濃度が目標值よりも高く $(\triangle C O=\mathrm{N})$ かつ上 昇中 $\left(\triangle^{2} C O=\mathrm{N}\right)$ ならば，エアダンパの開度を小さく する $(\Delta D=\mathrm{N})$.」となる.

\section{5 シミュレーション結果}

様々な目標值を設定し, 燃料の量およびエアダンパ の開度には制限を加えず，シミュレーションを行った。 シミュレーション結果の一例を Fig. 5 に示す. サンプ リング時間は 5 分とした.

420 分までの完全燃焼状態での制御では, 良好な結果 を得ている. 420 分経過後, 不完全燃焼状態にさせるが, 乙のとき, 一酸化炭素濃度の上昇之共に炬内温度が低下 している. これは, 炬内が酸素不足となるので燃料がス が十分に燃焼せず熱量が得られないためである. この温 度低下は，実際の焼成に打いても問題となっている。

\section{6 実炉実験結果}

Fig. 5 のシミュレーションと同じ目標值で害炬実験を 


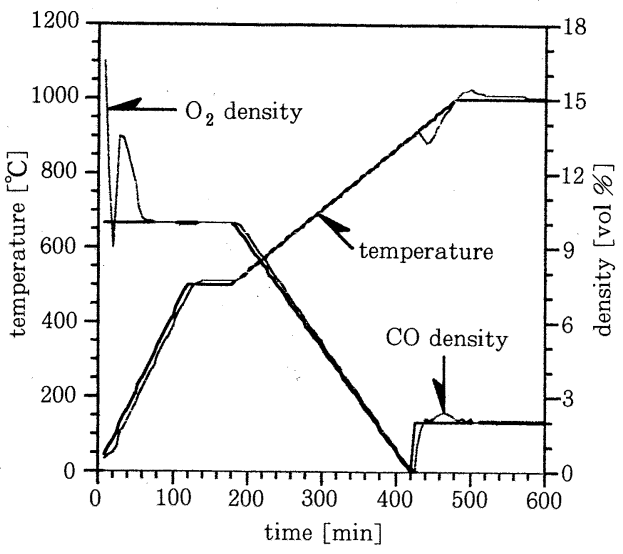

(a) Outputs

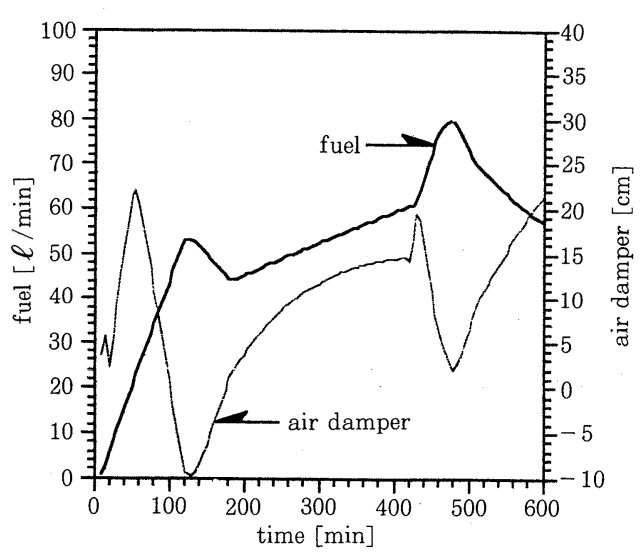

(b) Inputs

Fig. 5 Simulational results

行った結果を Fig. 6 に示す.ただし，サンプリング時 間は 1 分である.

本焼成炉の燃料ガス供給量の最大值は $100 \ell / \mathrm{min}$ で あり，また，下限值は $29 \ell / \mathrm{min}$ である．乙れは，燃料 ガス供給量がこの值を下回るとガスバーナの炎が消える 可能性があるからである，ガスバーナは，焼成炉の左右 に9本ずつ取り付けてあり，一度に点火するのではなく 30 分でとに 6 本ずつ点火した. また, エアダンパの開度 の最大值は $20 \mathrm{~cm}$ である．乙こで，エアダンパが開き 切ったとき, あるいは閉じ切ったとき, ゲートダンパを $5 \mathrm{~cm}$ 押し込む，あるいは引き出すあのとした.

焼成開始時の炉内温度之雾囲気の乱れは, ガスバーナ の点火によるものである. 120 180 分の間, 目標温度を $500{ }^{\circ} \mathrm{C}$ で一定としているが, 炉内温度は上昇を続けてい る. これは, 燃料ガス供給量が下限值に達したため, こ れ以上燃料ガス供給量を減らせないからである。乙のよ

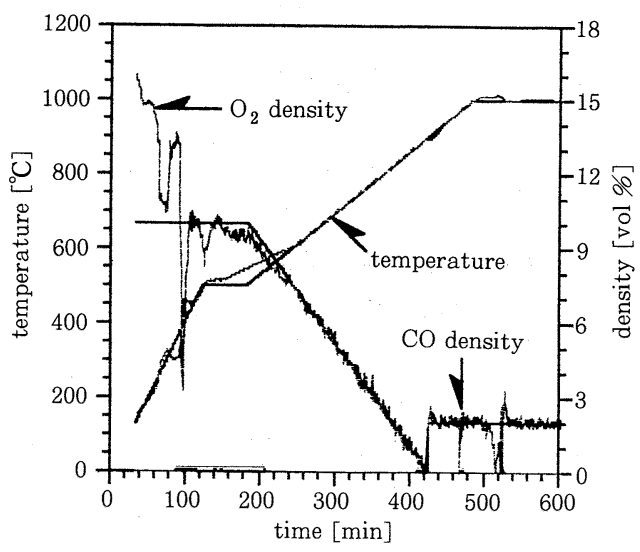

(a) Outputs

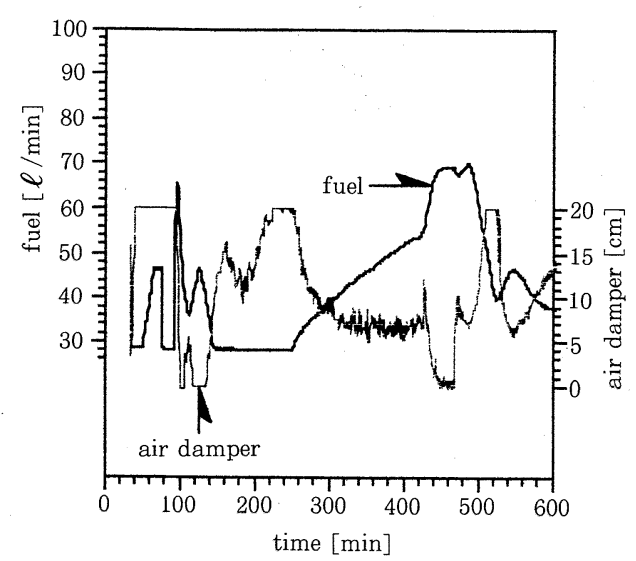

(b) Inputs

Fig. 6 Experimental results for real kiln

うな点を除けば，完全燃焼時の制御はほぼ良好なあので ある。

不完全燃焼時の温度低下は，シミュレーションのそれ と比べてかなり小さい，乙れは，サンプリング時間の違 いによるあのと考えられる. 465 分之 510 分でエアダン パの開度か限界に達したので, ゲートダンパを操作した. その結果，炉内の雾囲気が乱れたが，すぐにエアダンパ の操作により雾囲気の乱れが修正されていることがわか る.

以上より，実炉に扔いてあほぼ良好な制御を行えてい ることがわかる。

\section{5.あとがき}

本論では，まず燃焼理論に基づき焼成炉のモデリング を行った，つぎに，てのモデルを用いファジィ制御によ るシミュレーションを行った。 そして, 実炬へ適用し実 
験を行った．その実験結果はシミュレーションと同様良 好なものであった．以上より，焼成炬へのファジィ制御 の適用が有効であると共に, 本モデルの正当性む示すて とができた。

現在,さらに実炉実験を重ね

（1）気温や天候の違いによる，制御結果の変化

（2）不完全燃焼時の炉内温度の低下に対する改善

(3) ゲートダンパ操作の自動化

について検討している. また, 現在の制御は精度に重点 を置いているが,

（4）省エネルギー化を考慮した制御

を行うために,さらに熟練者の知識の抽出を検討してい る.

\section{参 考 文 献}

1) 今西, 横瀬, 宇田, 松本 : LPG 焚シャトル陶器焼成炬の効 率的な操炉方法の検討について; 昭和 54 年度滋賀県立信 楽窯業試験場業務報告, pp. 33 41 (1980)

2) 菅野: ファジィ制御，日刊工業新聞社 (1988)

3）電子情報通信学会 (編): 実用ファジィ制御技術, 電子情報 通信学会 (1991)

4) 伊藤, 亀井, 井上, 小川, 井上: 焼成炬に対するファジィ 制御の適用一焼成炉のモデリングについて一; 平成 3 年電 気関係学会関西支部連合大会講演論文集, p. G 42 (1991)

5) 橋本, 大島 : バッチプロセス制御の現状と将来; システム/ 制御/情報, Vol. 35, No. 3, pp. 123 131 (1991)

6) 西谷：モデル予測制御の応用; 計測と制御, Vol. 28 , No. 11, pp. 996 1004 (1989)

7) 夈田, 亀井, 井上, 小川, 中島：ファジィ制御による陶器 燒成炉の温度 ・雾团気制御; 第 37 回システム制御情報学 会研究発表講演会講演論文集, pp. 503 504 (1993)

8) 水谷: 燃焼工学 (第 2 版), 森北出版 (1989)

9) W. Trinks and M. H. Mawhinney (鈴木, 井田 (訳)) : 改 定工業用加熱炉，コロナ社 (1961)

10）菅田, 大石, 近藤, 桜井 (編): 電気 - 電子・情報・制御, 基礎工学ハンドブック，オーム社, pp. 889〜891 (1974)

\section{付 録}

\section{付録 1 流入空気量の逆算}

まず，ブタン，プロパンの完全燃焼式8) を示す．乙こ で, 燃焼反応や計測のむだ時間は無視できるあのとする.

$$
\begin{array}{r}
\mathrm{C}_{4} \mathrm{H}_{10}+\frac{13}{2} \mathrm{O}_{2}=4 \mathrm{CO}_{2}+5 \mathrm{H}_{2} \mathrm{O}(\mathrm{g})+118.5\left[\mathrm{MJ} / \mathrm{m}_{\mathrm{N}}{ }^{3}\right] \\
\mathrm{C}_{3} \mathrm{H}_{8}+5 \mathrm{O}_{2}=3 \mathrm{CO}_{2}+4 \mathrm{H}_{2} \mathrm{O}(\mathrm{g})+91.15\left[\mathrm{MJ} / \mathrm{m}_{\mathrm{N}}^{3}\right]
\end{array}
$$

こてで, $\mathrm{m}_{\mathrm{N}}{ }^{3}$ の $\mathrm{N}$ はnormal を表わし, $101.3 \mathrm{kPa}, 0{ }^{\circ} \mathrm{C}$ に扔ける $1 \mathrm{~m}^{3}$ の意味である。

一方，不完全燃焼の場合，その様子を一つの式で表わ すのは困難であるが，乙こでは不完全燃焼式8) を次式で 代表させるあのとする.

$$
\begin{aligned}
& \mathrm{C}_{4} \mathrm{H}_{10}+2 \mathrm{O}_{2}=4 \mathrm{CO}+5 \mathrm{H}_{2}+14.03\left[\mathrm{MJ} / \mathrm{m}_{\mathrm{N}}{ }^{3}\right] \\
& \mathrm{C}_{3} \mathrm{H}_{8}+\frac{3}{2} \mathrm{O}_{2}=3 \mathrm{CO}+4 \mathrm{H}_{2}+10.10\left[\mathrm{MJ} / \mathrm{m}_{\mathrm{N}}{ }^{3}\right]
\end{aligned}
$$

このとき, 炉内の不完全燃焼の程度は極端に強いあので はない（一酸化炭素が 2〜3\%) ので,すべての燃料ガ スが (A3)，(A4) 式の不完全燃焼をする程度の空気は あるあのとする.

いま，燃料ガス供給量を $F[\ell / \mathrm{min}]$ とし，そのうち 完全燃焼している量を $F_{1}$, 不完全燃焼している量を $F_{2}$ とする．また，流入空気量を $B[\ell / \mathrm{min}]$ とし，そのう ち完全燃焼に関係している量を $B_{1}$, 不完全燃焼に関係 している量を $B_{2}$ とする，さらに，ブタンに関係してい る量とプロパンに関係している量を区別して，それぞれ $B_{11}, B_{12}$ および $B_{21}, B_{22}$ とする.

燃料組成は, ブタン:プロパン $=7: 3$ であるてとを考 慮に入れて完全燃焼打よび不完全燃焼した後の気体量を 計算すると次のようになる.

完全燃焼・ブタン：

$$
\begin{aligned}
& 0.7 F_{1}+B_{11}+0.7 F_{1} \times\left(-1-\frac{13}{2}+4+5\right) \\
& =B_{11}+1.75 F_{1}
\end{aligned}
$$

完全燃焼・プロパン：

$$
\begin{aligned}
& 0.3 F_{1}+B_{12}+0.3 F_{1} \times(-1-5+3+4) \\
& \quad=B_{12}+0.6 F_{1}
\end{aligned}
$$

不完全燃焼・ブタン:

$$
\begin{aligned}
& 0.7 F_{2}+B_{21}+0.7 F_{2} \times(-1-2+4+5) \\
& \quad=B_{21}+4.9 F_{2}
\end{aligned}
$$

不完全燃焼・プロパン：

$$
\begin{gathered}
0.3 F_{2}+B_{22}+0.3 F_{2} \times\left(-1-\frac{3}{2}+3+4\right) \\
=B_{22}+1.65 F_{2}
\end{gathered}
$$

以上より, 燃焼後の気体量は,

$$
\begin{aligned}
& \left(B_{11}+1.75 F_{1}\right)+\left(B_{12}+0.6 F_{1}\right)+\left(B_{21}+4.9 F_{2}\right) \\
& +\left(B_{22}+1.65 F_{2}\right) \\
& \quad=B+2.35 F_{1}+6.55 F_{2}[\ell / \mathrm{min}]
\end{aligned}
$$

となり, このうち燃焼反応後残存している酸素の気体量 は, 窒素：酸素 $=79: 21$ とすると次のようになる.

完全燃焼・ブタン：

$$
0.21 B_{11}-0.7 F_{1} \times \frac{13}{2}=0.21 B_{11}-4.55 F_{1} \text {. }
$$

完全燃焼・プロパン:

$$
0.21 B_{12}-0.3 F_{1} \times 5=0.21 B_{12}-1.5 F_{1}
$$


不完全燃焼・ブタン：

$$
0.21 B_{21}-0.7 F_{2} \times 2=0.21 B_{21}-1.4 F_{2}
$$

不完全燃焼・プロパン：

$$
0.21 B_{22}-0.3 F_{2} \times \frac{3}{2}=0.21 B_{22}-0.45 F_{2}
$$

合計 :

$$
0.21 B-6.05 F_{1}-1.85 F_{2}[\ell / \mathrm{min}]
$$

(A 9), (A 10) 式より, 炉内の酸素濃度は,

$$
(\text { 炉内の酸素濃度 })=\frac{0.21 B-6.05 F_{1}-1.85 F_{2}}{B+2.35 F_{1}+6.55 F_{2}}
$$

となる. しかし, センサで組成成分を分析するとき, 燃 焼ガス中の水蒸気は管の中で凝縮, 除去されるので, 分 析は燃焼ガスから水蒸気を除いた乾き燃焼ガスに対して 行われることになる. 燃焼反応後の気体量 $B+2.35 F_{1}+$ $6.55 F_{2}$ のうち水蒸気の量は,

$$
0.7 F_{1} \times 5+0.3 F_{1} \times 4=4.7 F_{1}
$$

であるので, 酸素濃度の測定值を $y_{O 2}\left(0 \leq y_{O 2} \leq 1\right)$ と すると次の式が成り立つ.

$$
\begin{aligned}
y_{O 2}= & \frac{0.21 B-6.05 F_{1}-1.85 F_{2}}{B+2.35 F_{1}+6.55 F_{2}-4.7 F_{1}} \\
= & \frac{0.21 B-6.05 F_{1}-1.85 F_{2}}{B-2.35 F_{1}+6.55 F_{2}}
\end{aligned}
$$

また，一酸化炭素濃度の測定值を $y_{C O}\left(0 \leq y_{C O} \leq 1\right)$ とすると次のようになる.

$$
y_{C O}=\frac{3.7 F_{2}}{B-2.35 F_{1}+6.55 F_{2}}
$$

以上より, $F_{1}, F_{2}, B$ が次のように求まる.

$$
\begin{gathered}
F_{1}=\frac{3.7\left(0.21-y_{O 2}\right)+(-1.85-0.21 \times 6.55) y_{C O}}{3.7\left(0.21-y_{O 2}\right)+(4.2-0.21 \times 8.9) y_{C O}} F \\
{[\ell / \mathrm{min}] \quad(\mathrm{A} 15)} \\
F_{2}=\frac{(6.05-0.21 \times 2.35) y_{C O}}{3.7\left(0.21-y_{O 2}\right)+(4.2-0.21 \times 8.9) y_{C O}} F \\
{[\ell / \mathrm{min}] \quad(\mathrm{A} 16)} \\
B=\frac{6.05-2.35 y_{O 2}+\frac{2.35 \times 4.2-8.9 \times 6.05}{3.7} y_{C O}}{0.21-y_{O 2}+\frac{4.2-0.21 \times 8.9}{3.7} y_{C O}} F
\end{gathered}
$$

付録 2 炉の温度上昇に利用される熱量

焼成炉の熱勘定をする場合，入熱，出熱は次のような あのが考えられる ${ }^{8)}$ : なお，顕熱および潜熱の值は定压 下のあのであるから，比熱には定圧比熱を用いて表わす。
(1) 入熱

（i ）燃料の持ち込む熱量 $Q_{11}$ 燃料の発熱と, 外気温度 $T_{0}$ を基準とした顕熱との和 として与えられる. 燃料の送入温度は外気温度と等しい とすると顕熱は零となり， $Q_{11}$ は発熱量 $H_{l}$ となる.

$$
Q_{11}=H_{l}+c_{p f}\left(T_{f}-T_{0}\right)=H_{l}
$$

$H_{l}$ : 燃料の発熱量

$c_{p f}:$ 燃料の定圧比熱

$T_{f}:$ 燃料の送入温度

$T_{0}$ : 外気温度

（ii）空気の持ち込む熱量 $Q_{12}$

空気の送入温度は外気温度と等しいため, 空気の持ち 込む熱量 $Q_{12}$ は零となる.

（iii）被加熱物の持ち込む熱量 $Q_{13}$

被加熱物の送入温度は外気温度と等しいため, 被加熱 物の持ち込む熱量 $Q_{13}$ は零となる.

（iv）被加熱物の化学反応による熱量 $Q_{14}$

化学反応の発熱量は, 焼成物や釉薬の種類によって異 なり，また，反応が起てる程度む温度によって異なるた め, 取り扱いが困難である. しかし，その反応が起てる 温度が $300 \sim 700{ }^{\circ} \mathrm{C}$ で徐々に煎り焚きしている段階であ り，主に制御の中心となる温度はそれより高いとてろで ある. したがって，乙こでは零であるあのとする.

\section{(2) 出熱}

（i ）被加熱物の持ち出す保有熱 $Q_{01}$

被加熱物を焼成中に炉から取り出す場合（溶鉱炉のよ うな場合）に計算に入れるが，乙こでは，温度上昇中に 焼成物を取り出すことはしないため零である.

（ii）被加熱物の化学反応による吸収熱 $Q_{02}$

入熱 $Q_{14}$ 亡同様零とする.

（iii）被加熱物から蒸発した水蒸気の持ち出す保有熱 $Q_{03}$

水蒸気の測定装置は現在炬には装備されておらず，被 加熱物から蒸発した水蒸気の量を測定できる状態ではな い. また, 蒸発するのは入熱 $Q_{14}$ の場合と同様低温時で あるので，零として考える.

（iv）燃焼ガスの持ち出す熱量 $Q_{04}$

外気温度 $T_{0}$ を基準とした湿り燃焼ガス（水蒸気を含 んだままの燃焼ガス）の顕熱として与えられる.

$$
Q_{04}=G_{g} c_{g}\left(T_{g}-T_{0}\right)
$$

$G_{g}:$ 燃焼ガス量（湿り燃焼ガス）

$c_{g}:$ 燃焼ガスの定圧比熱

$T_{g}$ : 排気温度

$T_{0}$ : 外気温度 
（v）炉壁から外へ放熱される熱量 $Q_{05}$

（vi）蓄熱される熱量 $Q_{06}$

以上の入熱出熱の関係は, 全体として次式を満たすすの である.

$$
\sum_{i=1}^{4} Q_{1 i}-\sum_{j=1}^{6} Q_{0 j}=0
$$

ここで，炉の温度上昇に利用される熱量を $Q$ とすると，

$$
Q=Q_{05}+Q_{06}
$$

であり, (A 20) 式より入熱の合計から, $Q_{05}, Q_{06}$ を除い た出熱の合計を差し引いたものとして与えられる.

$$
\begin{aligned}
Q & =\sum_{i=1}^{4} Q_{1 i}-\sum_{j=1}^{4} Q_{0 j}=Q_{11}-Q_{04} \\
\cdot & =H_{l}-G_{g} c_{g}\left(T_{g}-T_{0}\right)
\end{aligned}
$$

ここで, 炬内の圧力は僅かであるため, 簡単のため, 燃焼反応後の気体が炉内に蓄積することなく煙突から流 出するむのとすると, (A9) 式より,

$$
Q=H_{l}-\left(B+2.35 F_{1}+6.55 F_{2}\right) c_{g}\left(T_{g}-T_{0}\right)
$$

となる. ここで, $c_{g}$ は定圧比熱であり，

$$
c_{g}=\frac{5}{2} R=2.5 \times 8.31[\mathrm{~J} / \mathrm{K} \cdot \mathrm{mol}]
$$

である.乙のとき, 炉内圧力は外圧に比較して 0.25 $\mathrm{mmAp} \sim 1.2 \mathrm{mmAp}(1 \mathrm{mmAp} \fallingdotseq 0.001 \mathrm{~atm})$ 程度高 いだけであり，ほとんど変化がない. $1 \mathrm{~mol}$ の体積は $1 \mathrm{~atm}, 0{ }^{\circ} \mathrm{C}$ で $22.4 \ell$ であるが, 圧力一定であるならば 温度 $T$ の関数として

$$
\left(1+\frac{T}{273}\right) 22.4
$$

と表わされる. 温度 $T$ が外気温度 $T_{0}$ と等しいとき, $c_{g}$ は

$$
c_{g}=\frac{2.5 \times 8.31}{\left(1+\frac{T_{0}}{273}\right) 22.4}[\mathrm{~J} / \mathrm{K} \cdot \ell]
$$

と表わされ, さらに, 発熱量 $H_{l}$ の総量は,

$$
\begin{gathered}
H_{l}=F_{1}(0.7 \times 118.5+0.3 \times 91.15) \\
+F_{2}(0.7 \times 14.03+0.3 \times 10.1) \\
{\left[\mathrm{J} / \mathrm{min} \times \mathrm{MJ} / \mathrm{m}_{\mathrm{N}}{ }^{3}\right]} \\
=110295 F_{1}+12851 F_{2}[\mathrm{~J} / \mathrm{min}] \\
\left(\because 1\left[\mathrm{~m}_{\mathrm{N}}{ }^{3}\right]=10^{-3}[\ell]\right) \quad(\mathrm{A} 27)
\end{gathered}
$$

であるので, 炉の温度上昇に利用される熱量 $Q$ は次式の ようになる。

$$
\begin{gathered}
Q=110295 F_{1}+12851 F_{2} \\
-\left(B+2.35 F_{1}+6.55 F_{2}\right) \frac{2.5 \times 8.31}{\left(1+\frac{T_{0}}{273}\right) 22.4}\left(T_{g}-T_{0}\right) \\
{[\mathrm{J} / \mathrm{min}] \quad(\mathrm{A} 28)}
\end{gathered}
$$


